\title{
Does leaf resorption efficiency always predict plant nutrient status? A case study from a common mangrove species in China
}

\author{
Lili Wei ${ }^{1}$, Ming Yang Bee ${ }^{1}$, Poh Seng Chee ${ }^{1}$, Ankit Garg ${ }^{1}$, Yangyang $\mathrm{Wu}^{1}$, Tingfeng \\ Zhang ${ }^{1}$, Hongyong Fan ${ }^{1}$, Jie Li ${ }^{1}$, Lin Liu ${ }^{1}$, Xu Huang ${ }^{1}$, and Chaoxiang Liu ${ }^{1}$ \\ ${ }^{1}$ Affiliation not available
}

July 7,2020

\begin{abstract}
Aims The impact of nutrient increase on nutrient resorption from senescent leaves is an important topic, which is not completely understood. Mangrove species are characterized by nutrient conservation mechanisms as a consequence of adaptation to nutrient-poor environments. The understanding of the response of the traits related to nutrient conservation strategies to nutrient availability is limited. This study aims to address whether nutrient resorption of mangrove species is responsive to long-term nutrient enrichment. Methods A field-based study was carried out in a Kandelia obovata dominated mangrove stand where a nutrient gradient was generated by the long-term discharge of aquaculture wastewater. Seasonal variations of nutrient resorption and nutrient availability were assessed. Important findings The data from summer and winter showed the same results: 1) resorption proficiency or the nutrient concentrations ( $\mathrm{N}$ and $\mathrm{P}$ ) in senescent leaves did not varied with nutrient increases except the plot that the $\mathrm{N}$ availability was extremely high; 2) the resorption efficiency of both $\mathrm{N}$ and $\mathrm{P}$ was positively correlated with nutrient availability, and $\mathrm{N}$ resorption efficiency was also positively correlated to leaf $\mathrm{N}$ : $\mathrm{P}$ ratio; 3) $\mathrm{N}$ resorption was complete while the resorption of $\mathrm{P}$ was incomplete. These results indicate that resorption proficiency of K. obovata is less sensitive than resorption efficiency to nutrient availability, and the positive response of $\mathrm{N}$ resorption efficiency is related to the imbalance of nutrient availability, while the positive response of $\mathrm{P}$ resorption efficiency is unrelated to plant nutrient status. We suggest that caution should be taken in using resorption efficiency of mangrove species to predict plant nutrient status.
\end{abstract}

Methods

A field-based study was carried out in a Kandelia obovata dominated mangrove stand where a nutrient gradient was generated by the long-term discharge of aquaculture wastewater. Seasonal variations of nutrient resorption and nutrient availability were assessed.

Important findings

The data from summer and winter showed the same results: 1) resorption proficiency or the nutrient concentrations $(\mathrm{N}$ and $\mathrm{P})$ in senescent leaves did not varied with nutrient increases except the plot that the $\mathrm{N}$ availability was extremely high; 2) the resorption efficiency of both $\mathrm{N}$ and $\mathrm{P}$ was positively correlated with nutrient availability, and $\mathrm{N}$ resorption efficiency was also positively correlated to leaf $\mathrm{N}$ : $\mathrm{P}$ ratio; 3 ) $\mathrm{N}$ resorption was complete while the resorption of $\mathrm{P}$ was incomplete. These results indicate that resorption proficiency of $K$. obovata is less sensitive than resorption efficiency to nutrient availability. The positive response of $\mathrm{N}$ resorption efficiency is related to the imbalance of nutrient availability, while the positive response of $\mathrm{P}$ resorption efficiency is unrelated to plant nutrient status. We argue that caution should be taken in using the resorption efficiency of mangrove species to predict plant nutrient status.

Key words:Complete resorption, Imbalance of nutrient availability, Incomplete resorption, Nutrient resorption, Resorption proficiency, Senescent leaf. 


\section{Introduction}

Plants that live in the nutrient-poor environments have nutrient conservation mechanisms that enable them to survive in the infertile environments. However, nutrient eutrophication in coastal environment due to aquaculture activities has been a global problem, which can impact the growth of mangrove plants. Understanding how nutrient conservation strategies of mangrove species respond to nutrient enrichment is necessary for predicting ecosystem functions in a changing environment.

Nutrient resorption is one of the most important nutrient conservation strategies, through which a plant transports nutrients from senescent leaves to other tissues (Aerts, 1996). This resorption process requires more energy compared to taken up nutrients from roots (Kobe et al., 2005). It is therefore expected that plants reuse nutrients less efficiently when nutrient availability increases. Many results including a metaanalysis from a globe data set have indicated a negative correlation between resorption efficiency and leaf nutrient status, both within and among species (Kobe et al., 2005; Vergutz et al., 2012; Yuan \& Chen, 2015), while a positive correlation was also found in a few studies but restricted in the natural communities without disturbances (Sabaté et al., 1995).

Although nutrient availability determines plant nutrient resorption efficiency, plant nutrient demands and other factors may also drive plant resorption efficiency. For example, trees with greater reproductive demands had higher resorption efficiency than trees with smaller reproductive requirment (Tully et al. 2013). Slow growing species or conservative species may be unresponsive to nutrient availability based on the hypothesis that being fast or slow is a general feature of a species (Reich 2014).

Resorption proficiency - the level to which a nutrient is reduced during senescence (Killingbeck, 1996) can also indicate nutrient resorption. Higher proficiency corresponds with lower nutrient concentrations in senescent leaves (Van Heerwaarden et al., 2003b). Resorption proficiency seems to be more responsive than resorption efficiency to nutrient availability particularly for wetland plants (Rejmánková, 2005; Van Heerwaarden et al., 2003b). We expected that resorption proficiency is more responsive to nutrient supply than do resorption efficiency.

This study aims to examine: 1) is nutrient resorption negatively responding or unresponsive to nutrient increases; 2) is the response of nutrient resorption to nutrient availability related to plant nutrient status.

\section{Materials and Methods}

\section{Experimental design and study site}

Compared with simulation experiment, field study has the advantage that can examine the long-term response of plant to nutrient increases. Further, within-stand study can minimize the effects of the heterogeneity of local environments among sites. We selected a mangrove stand $\left(24^{\circ} 26^{\prime} \mathrm{N} ; 117^{\circ} 54^{\prime} \mathrm{E}\right)$ between two creeks, where Kandelia obovata (a common mangrove species in China) is the predominant species. These creeks have been received the effluents from aquaculture ponds for nearly ten years. Tidal water (mixed with aquaculture effluents) inundation across the plots between creeks generated a nutrient gradient ranged from $1.4 \mathrm{~g} \mathrm{~kg}^{-1}$ to $2.7 \mathrm{~g} \mathrm{~kg}^{-1}$ for $\mathrm{N}$ and from $0.58 \mathrm{~g} \mathrm{~kg}^{-1}$ to $2.76 \mathrm{~g} \mathrm{~kg}^{-1}$ for $\mathrm{P}$ (data shown in Table S1). Based on this nutrient gradient we assessed the responses of the nutrient resorption of $K$. obovata .

\section{Sampling and analysis}

We collected the leaves and sediment cores (top $10 \mathrm{~cm}$ ) in January (winter) and in August (summer) across six plots between two creeks (Creek I to the north side and Creek II to the south, the distance between these two creeks was $\sim 500 \mathrm{~m}$; Fig S1). For each plot, it is around $9 \mathrm{~m}^{2}(3 \times 3 \mathrm{~m})$ and the distance between plots was $\sim 80 \mathrm{~m}$. Ten to 20 leaves (mature or senescent) were sampled from each of the three trees in each plot. The leaves collected from the same tree were mixed representing for one sample, thereby three samples were obtained for each plot. The senescent leaves were obtained by shaking the branches lightly and selected the healthy yellow leaves just dropped off (Lin \& Wang, 2001). The sediment samples collected at four directions for each tree in each plot and mixed into one sample, then three sediment samples obtained in each plot. 
The concentrations of $\mathrm{N}$ and $\mathrm{P}$ in the samples were measured with a VarioMax Elemental Analyzer (Elementar, Hanau, Germany) and an inductively coupled plasma optical emission spectrometer (ICP-OES, Optima 5300 DV, Perkin Elmer, Waltham, MA, USA), respectively. We calculated the mass-based resorption efficiency of the leaf nutrients as $1-\frac{[\text { Nutrient }] \text { senescent }}{[\text { Nutrient }] \text { mature }} \times 100 \%$, where $[\text { Nutrient }]_{\text {senescent }}$ and $[\text { Nutrient }]_{\text {mature }}$ are nutrient concentrations $\left(\mathrm{mg} \mathrm{g}^{-1}\right)$ of the senescent and mature green leaves, respectively. Resorption proficiency was indicated by the nutrient concentrations in senescent leaves.

\section{Statistical data analysis}

Nutrient concentration and resorption were compared with two-way ANOVA, with the season as the fixed factor and the plot as the random factor, using LSD or Games-Howell post hoc-test to compare among plots. One-sample $t$-test was used to determine whether the resorption efficiency of plants in each plot differed from the global mean values. Pearson correlation analysis was used to predict the correlations between resorption efficiency and nutrient availability or the $\mathrm{N}$ : P ratio in green leaves. All the data analyses were run with SPSS (version 16.0) for Windows.

\section{Results}

\section{Variations of leaf nutrient concentrations}

The nutrients in mature green leaves varied with nutrient availability. The $\mathrm{N}$ ranged from $12.91 \mathrm{mg} \mathrm{g}^{-1}$ to $24.29 \mathrm{mg} \mathrm{g}^{-1}$ with $18.52 \mathrm{mg} \mathrm{g}^{-1}+-0.77 \mathrm{mg} \mathrm{g}^{-1}$ on average in summer, and ranged from $16.68 \mathrm{mg} \mathrm{g}^{-1}$ to 29.27 $\mathrm{mg} \mathrm{g}^{-1}$ with $22.03 \mathrm{mg} \mathrm{g}^{-1}+-1.04 \mathrm{mg} \mathrm{g}^{-1}$ on average in winter. The $\mathrm{P}$ in summer ranged from $1.19 \mathrm{mg} \mathrm{g}^{-1}$ to $1.87 \mathrm{mg} \mathrm{g}^{-1}$ and averaged $1.48 \mathrm{mg} \mathrm{g}^{-1}+-0.07 \mathrm{mg} \mathrm{g}^{-1}$, while $\mathrm{P}$ ranged from $1.27 \mathrm{mg} \mathrm{g}^{-1}$ to $2.04 \mathrm{mg} \mathrm{g}^{-1}$ and averaged $1.71 \mathrm{mg} \mathrm{g}^{-1}+-0.06 \mathrm{mg} \mathrm{g}^{-1}$ in winter.

However, there was no variation in senescent leaves across plots $\left(6.47 \mathrm{mg} \mathrm{g}^{-1}+-0.17 \mathrm{mg} \mathrm{g}^{-1}\right.$ of $\mathrm{N}$ and $0.98 \mathrm{mg}$ $\mathrm{g}^{-1}+-0.03 \mathrm{mg} \mathrm{g}^{-1}$ of $\mathrm{P}$ ), except the plot 2 where the concentration of $\mathrm{N}$ was much higher than the leaves from the other plots $(p<0.01$; Fig. 1).

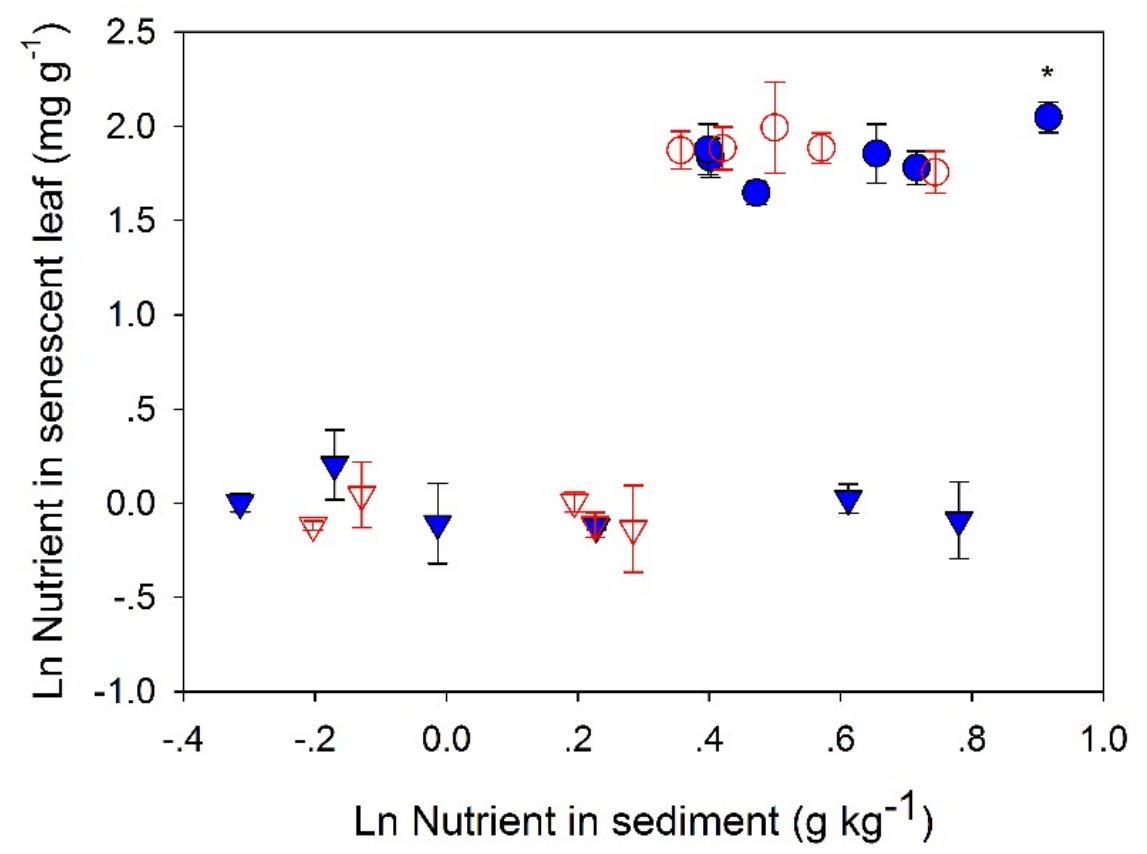


Figure 1: No variation of nutrient concentrations in senescent leaves in response to nutrient increases (aside from one plot). Circle and triangle represent nitrogen and phosphorus; solid (in blue) and open (in red) symbols indicate the data in winter and in summer respectively $\left(^{*}, p<0.05\right)$.

\section{Correlations between nutrient resorption and nutrient availability}

The resorption efficiency of both $\mathrm{N}$ and $\mathrm{P}$ showed positive responses to nutrient increases. The correlation for $\mathrm{N}$ was stronger in summer $\left(r^{2}=0.735, p=0.002\right)$ than that in winter $\left(r^{2}=0.374, p=0.139\right)$, while the correlation of $\mathrm{P}$ was similar in summer $\left(r^{2}=0.567, p=0.018\right)$ and in winter $\left(r^{2}=0.531, p\right.$ $=0.042$; Fig. 2). The average N: P ratio was $13.12 \pm 0.48$ (ranged $8.51-17.95)$ in mature green leaves, and $6.74 \pm 0.20$ (ranged $3.80-8.80$ ) in senescent leaves.
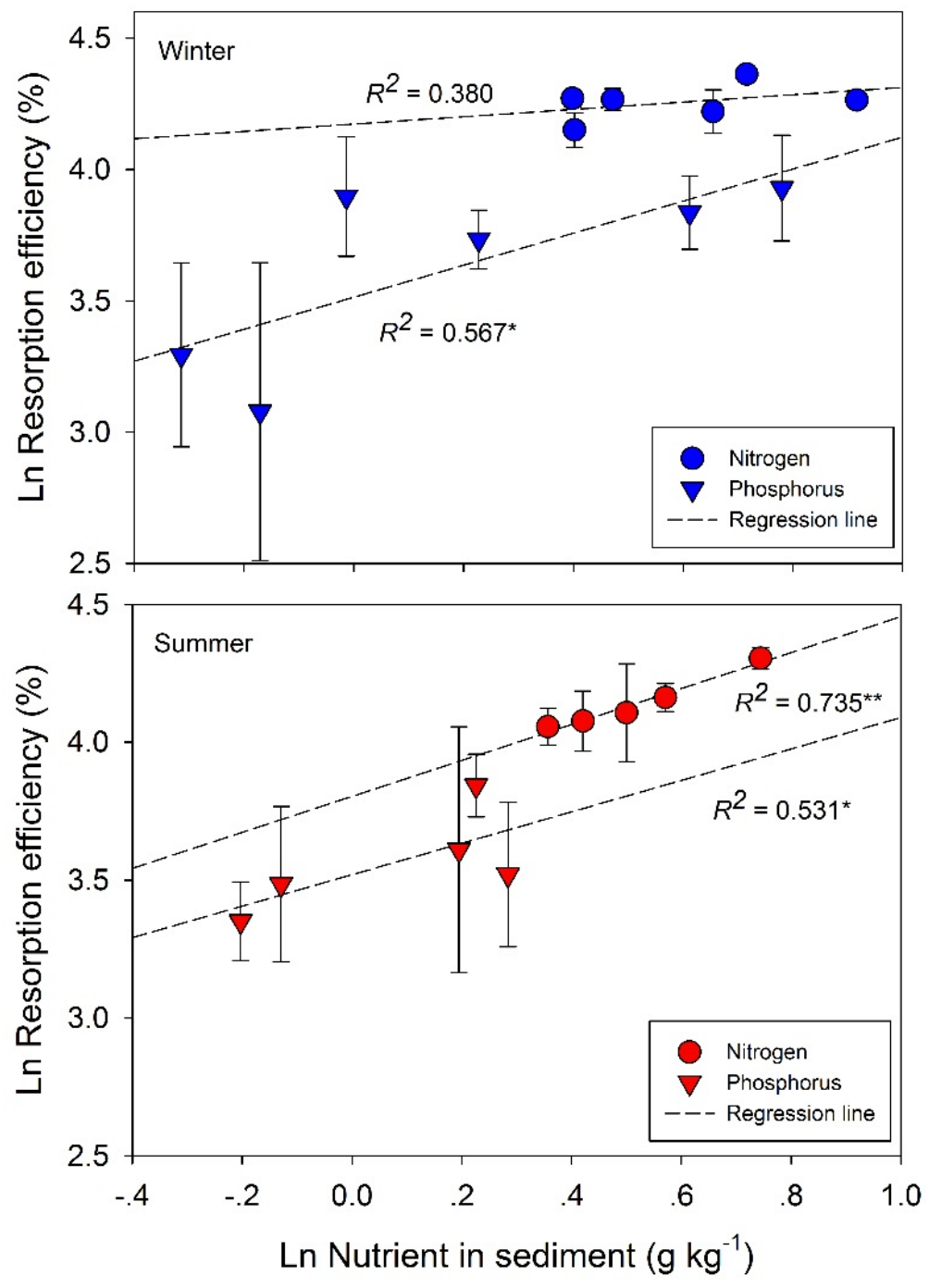

Figure 2: Positive correlations between resorption efficiency and nutrient availability in winter and in summer $\left(^{*}, p<0.05 ;^{* *}, p<0.01\right)$.

\section{Discussion}




\section{Resorption proficiency unresponsive to nutrient increases}

Resorption proficiency is commonly thought to be a sensitive indicator of changes in nutrient availability (Miao, 2004; Rejmánková, 2005). Most of these data are derived from herbaceous species, such as ephemeral herb, subarctic bog species, aquatic macrophytes, and sawgrass, which commonly showed rapid response to changes in nutrient availability (Anderson \& Eickmeier, 2000; van Heerwaarden et al., 2003b; Miao, 2004; Rejmánková, 2005). Feller et al. (2003b) found that $\mathrm{N}$ addition altered nutrients in senescent leaves of the mangrove species Avicennia germinans and Rhizophora mangle, but $\mathrm{P}$ addition had little effect. In our study, neither $\mathrm{N}$ nor $\mathrm{P}$ increases altered the nutrients in senescent leaves of $K$. obovata, unless the $\mathrm{N}$ availability was extremely high like in plot 2, indicating that the resorption proficiency for mangrove species may not be sensitive to nutrient increases. This is consistent with the observations that slow-growing species respond slowly to nutrient availability (Clausing \& Fong, 2016; Li et al., 2016).

\section{Resorption efficiencypositive response to nutrient increases}

The resorption efficiency of both $\mathrm{N}$ and $\mathrm{P}$ of $K$. obovata responded positively to nutrient increases (Fig. 2). In contrast, previous studies found that long-term nutrient increase generally caused the decrease of resorption efficiency, these plants included grasses (Lü et al., 2013), evergreen (Wang et al., 2014) or wetland species (Rejmánková, 2005; Mao et al., 2013). Such negative correlation was also observed in some mangrove species. For example, long-term P fertilization reduced leaf resorption efficiency by $20 \%-50 \%$ in dwarf Rhizophora mangle at Twin Cays, where $\mathrm{P}$ was limited for plant growth (Feller et al., 1999). However, in a 2-year fertilization study, a positive correlation was observed in a mangrove species (Avicennia germinans) growing in a hypersaline condition, which was properly the result of the interaction of salinity and nutrient stresses (Feller et al., 2003a). The interaction between salinity and nutrient stress cannot explain our observations, because our mangrove stand was low in salinity (electrical conductivity of $2.65 \mathrm{~ms} \mathrm{~cm}^{-1}$ ) and high in nutrient availability $\left(1.4 \mathrm{~g} \mathrm{~kg}^{-1}-2.7 \mathrm{~g} \mathrm{~kg}^{-1}\right.$ of $\mathrm{N}$ and $0.58 \mathrm{~g} \mathrm{~kg}^{-1}-2.76 \mathrm{~g} \mathrm{~kg}^{-1}$ of $\left.\mathrm{P}\right)$.

There is a potential underestimation of resorption efficiency by using mass-based calculation due to mass loss caused by carbon resorption, leaching, and in situ decomposition (van Heerwaarden et al. 2003a). However the senescent leaves we collected were fresh and dropped off by shaking the trees, as such there was no chance to process leaching and decomposition. And the carbon concentration of senescent leaves was slightly higher than that in green leaves (the t-test result was not significant; $P=0.90$ ). Therefore, the estimation of nutrient resorption by using mass-based resorption efficiency was feasibility.

\section{Complete resorption of nitrogen}

Positive and negative responses occur when nutrient resorption is complete and incomplete, respectively (Feller et al., 1999; 2003a). The resorption from senescent leaves is complete when $\mathrm{N}$ and $\mathrm{P}$ in senescent leaves reduced to concentrations below $0.7 \%$ and $0.05 \%$, respectively (Killingbeck, 1996).

$\mathrm{N}$ resorption efficiency (as high as $81 \%$ and averaged at $68 \% \pm 1 \%$ ) was greater than the global mean level $(\sim 50 \%, p<0.01$; Aerts, 1996) and $\mathrm{N}$ in senescent leaves $(0.59 \% \pm 0.14 \%)$ was less than $0.7 \%$, indicating a complete resorption of $\mathrm{N}$ of $K$. obovata(Killingbeck, 1996). These results are implying that $K$. obovata was still limited by $\mathrm{N}$ availability. Complete resorption commonly occurs in nutrient-poor environments. However, the nutrient availability was enriched in our stand. The sediment $\mathrm{N}\left(1.4 \mathrm{~g} \mathrm{~kg}^{-1}-2.7 \mathrm{~g} \mathrm{~kg}^{-1}\right)$ were close to those of heavily disturbed mangrove stands such as those in China's Zhanjiang Mangrove Reserve (2.65 g $\mathrm{kg}^{-1}$; Han \& Gao, 2013) and Thailand's Sawi Bay $\left(0.8 \mathrm{~g} \mathrm{~kg}^{-1}-2.7 \mathrm{~g} \mathrm{~kg}^{-1}\right.$; Alongi et al., 2001). The average senescent leaf $\mathrm{N}$ concentration in this study $\left(5.87 \mathrm{mg} \mathrm{g}^{-1}\right)$ was lower than the global mean value (e.g., Feller et al., 1999).

Base on the analysis above, we inferred that the complete resorption of $\mathrm{N}$ of $K$. obovata was not related to $\mathrm{N}$ availability but more likely due to the imbalance of the availability of N and P (Han et al., 2013; See et al., 2015). In general, a leaf $\mathrm{N}$ : $\mathrm{P}$ ratio below 13 implies limitation in $\mathrm{N}$, and one above 16 reflects a limitation in P (Güsewell \& Koerselman, 2002; Güsewell, 2004). In our study, the plants in most plots had a leaf N: P 
ratio below 13, indicating that $\mathrm{N}$ availability was limited due to the imbalance of the availability of $\mathrm{N}$ and $\mathrm{P}$.

The N: P ratio of green leaves is an important indication of nutrient availability (Güsewel, 2004), we performed an analysis of the correlation between $\mathrm{N}$ resorption efficiency and leaf $\mathrm{N}$ : $\mathrm{P}$ ratio. Results showed positive correlations in both winter $\left(r^{2}=0.574, p<0.05\right)$ and summer $\left(r^{2}=0.616, p<0.05\right)($ Figure 3). This is consistent with the observations of evergreen broadleaf species and conifers (Han et al., 2013). Despite there might be many mechanisms that control the nutrient resorption of plants, in our study the imbalanced availability of $\mathrm{N}$ and $\mathrm{P}$ was probably the main factor. Our previous study showed that the sedimentary $\mathrm{N}$ : $\mathrm{P}$ ratio of our stand was relatively low compared with global natural mangrove stands (Wei et al., 2017). These results indicated that the complete resorption of $\mathrm{N}$ and the positive response of $\mathrm{N}$ resorption efficiency to nutrient availability were related to the imbalance in plant nutrients.

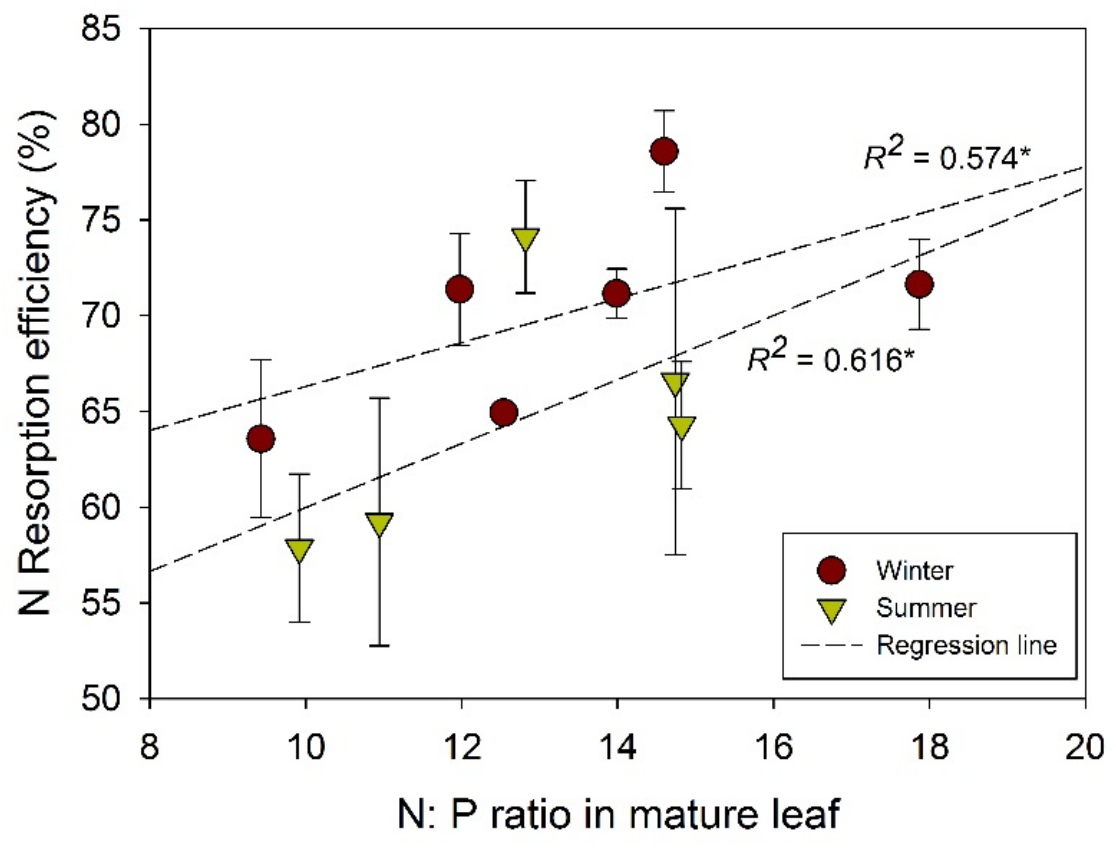

Figure 3: Positive correlation between $\mathrm{N}$ resorption efficiency and the $\mathrm{N}$ : $\mathrm{P}$ ratio of green leaves $\left(^{*}, p<\right.$ 0.05).

\section{Incomplete resorption of phosphorus}

In contrast, the $\mathrm{P}$ resorption efficiency of $K$. obovata $(35 \% \pm 3 \%)$ was substantially lower than the global level $(~ 52 \%, p<0.01$; Aerts, 1996), and the concentrations in senescent leaves $(0.12 \% \pm 0.05 \%)$ was above $0.05 \%$, indicating an incomplete resorption of $\mathrm{P}$ (Killingbeck, 1996). Incomplete nutrient resorption means that plant does not rely mainly on nutrient resorption, which occurs when nutrient availability meets the demands for plant growth. The $\mathrm{P}$ availability $\left(0.58 \mathrm{~g} \mathrm{~kg}^{-1}-2.76 \mathrm{~g} \mathrm{~kg}^{-1}\right)$ in our stand was much higher than most other mangrove stands (e.g. Alongi et al., 2003; Lovelock et al., 2004; Han \& Gao, 2013), which may indicate that $\mathrm{P}$ availability has met the demand of plant in our study. As such, the positive response of $\mathrm{P}$ resorption efficiency to nutrient increases was not due to the increase of nutrient reuse from senescent leaves but more likely the results of the increase of nutrient uptake from roots. The non-significant correlation between $\mathrm{P}$ resorption efficiency and the $\mathrm{N}: \mathrm{P}$ in green leaves $(P>0.05)$ indicated that the positive response of $\mathrm{P}$ resorption was unrelated to plant nutrient status. We therefore suggest that caution should be taken in using resorption efficiency of mangrove species to predict plant nutrient status. 
Despite our study targeted at only one species, this selected mangrove species is often predominated in mangrove forests even forms a pure stand in China. Further, we examine the variations of leaf traits in two seasons and found the same response patterns. As such, our study offers reliable evidence for our findings.

\section{Conclusion}

For the common mangrove species, the resorption proficiency of its leaves was less responsive to nutrient increases compared with resorption efficiency. Positive response of $\mathrm{N}$ resorption efficiency to nutrient increases was related to $\mathrm{N}$ limitation, while the positive response of the resorption efficiency of $\mathrm{P}$ was unrelated to plant nutrient status.

Acknowledgements: We thank the comments from Catherine Lovelock at the University of Queensland. The mangrove forest is owned and operated by the Forest Bureau of Longhai, China.

Funding: This work was funded by National Natural Science Foundation of China (31570400) and The State Key Laboratory of Marine Environmental Science at Xiamen University (MEL Visiting Fellowship, MELRS1312).

Conflicts of Interest: The authors declare no competing financial interests.

Author Contributions:LW and MYB conceived and designed the experiments. MYB, LW, YW, TZ, HF, and JL conducted the experiments, performed the analyses, and collected the data. PSC, AG, LL, XH, and CL read and edited the manuscript. All authors approved the final manuscript.

\section{ORCID}

Lili Wei https: // orcid. org/0000-0002-9208-7240

\section{Data Accessibility:}

- Sampling locations, morphological data and microsatellite genotypes: Dryad doi: 10.5061/dryad.rbnzs7h8s

\section{References}

Aerts R (1996) Nutrient resorption from senescing leaves of perennials: are there general patterns? J Ecol:597608. DOI: $10.2307 / 2261481$

Alongi DM, Wattayakorn G, Pfitzner J, et al (2001) Organic carbon accumulation and metabolic pathways in sediments of mangrove forests in southern Thailand. Mar Geol 179:85-103. https://doi.org/10.1016/S00253227(01)00195-5

Alongi DM, Chong VC, Dixon P, et al (2003) The influence of fish cage aquaculture on pelagic carbon flow and water chemistry in tidally dominated mangrove estuaries of peninsular Malaysia. Mar Environ Res 55:313-333.

https://doi.org/10.1016/S0141-1136(02)00276-3

Anderson WB, Eickmeier WG (2000) Nutrient resorption in Claytonia virginica L.: implications for deciduous forest nutrient cycling. Can J Bot 78(6):832-839. https://doi.org/10.1139/b00-056

Chen FS, Chong VC, Dixon P (2015) Nitrogen and phosphorus additions alter nutrient dynamics but not resorption efficiencies of Chinese fir leaves and twigs differing in age. Tree physiol 35:1106-1117. https://doi.org/10.1093/treephys/tpv076

Clausing RJ, Fong P (2016) Environmental variability drives rapid and dramatic changes in nutrient limitation of tropical macroalgae with different ecological strategies. Coral Reefs 35:669-680. https://doi.org/10.1007/s00338-016-1403-6

Feller IC, Whigham DF, O'Neill JP (1999) Effects of nutrient enrichment on within-stand cycling in a mangrove forest. Ecology 80:2193-205. 
https://doi.org/10.1890/0012-9658(1999)080[2193:EONEOW]2.0.CO;2

Feller IC, McKee KL, Whigham DF (2003a) Nitrogen vs. phosphorus limitation across an ecotonal gradient in a mangrove forest. Biogeochemistry 62:145-175.

https://doi.org/10.1023/A:1021166010892

Feller IC, Whigham DF, McKee KL, Lovelock CE (2003b) Nitrogen limitation of growth and nutrient dynamics in a disturbed mangrove forest, Indian River Lagoon, Florida. Oecologia 134: 405-414.

Gusewell S (2004) N: P ratios in terrestrial plants: variation and functional significance. New Phyt 164:243266.

https://doi.org/10.1111/j.1469-8137.2004.01192.x

Gusewell S, Koerselman W (2002) Variation in nitrogen and phosphorus concentrations of wetland plants. Perspect Plant Ecol Syst 5:37-61.

https://doi.org/10.1078/1433-8319-0000022

Han W, Gao X (2013) Study on the soil physical and chemical characteristics of mangrove forest in Zhanjiang Bay. Chin Agricult Sci Bulle 29:27-31

Han W, Tang L, Chen Y, Fang J (2013) Relationship between the Relative Limitation and Resorption Efficiency of Nitrogen vs Phosphorus in Woody Plants. PLoS ONE 8(12): e83366. doi:10.1371/journal.pone.0083366

Killingbeck KT (1996) Nutrients in senesced leaves: keys to the search for potential resorption and resorption proficiency. Ecology 77:1716-1727.

https://doi.org/10.2307/2265777

Kobe RK, Lepczyk CA, Iyer M (2005) Resorption efficiency decreases with increasing green leaf nutrients in a global data set. Ecology 86:2780-2792.

https://doi.org/10.1890/04-1830

Li J, Guo Q, Zhang J, Korpelainen H, Li C (2016) Effects of nitrogen and phosphorus supply on growth and physiological traits of two Larix species. Environ. Exp Bot 130:206-215. https://doi.org/10.1016/j.envexpbot.2016.06.006

Lin P, Wang WQ (2001) Changes in the leaf composition, leaf mass and leaf area during leaf senescence in three species of mangroves. Ecological Engineering 16(3): 415-424. https://doi.org/10.1016/S09258574(00)00126-9

Lovelock CE, Feller IC, McKee KL (2004) The effect of nutrient enrichment on growth, photosynthesis and hydraulic conductance of dwarf mangroves in Panama. Funct Ecol 18:25-33. https://doi.org/10.1046/j.02698463.2004.00805.x

Lu XT, Reed S, Yu Q (2013) Convergent responses of nitrogen and phosphorus resorption to nitrogen inputs in a semiarid grassland. Global Change Biol 19:2775-2784. https://doi.org/10.1111/gcb.12235

Mao R, Song CC, Zhang XH (2013) Response of leaf, sheath and stem nutrient resorption to 7 years of N addition in freshwater wetland of Northeast China. Plant Soil 364:385-394. https://doi.org/10.1007/s11104012-1370-9

Miao S (2004) Rhizome growth and nutrient resorption: mechanisms underlying the replacement of two clonal species in Florida Everglades. Aquatic Botany 78: 55-66. https://doi.org/10.1016/j.aquabot.2003.09.001

Reef R, Feller IC, Lovelock CE (2010) Nutrition of mangroves. Tree Physiol 30:1148-1160. https://doi.org/10.1093/treephys/tpq048 
Reich, PB (2014) The world-wide 'fast-slow'plant economics spectrum: a traits manifesto. Journal of Ecology 102(2):275-301.

https://doi.org/10.1111/1365-2745.12211

Rejmankova E (2005) Nutrient resorption in wetland macrophytes: comparison across several regions of different nutrient status. New Phyt 167:471-482.

https://doi.org/10.1111/j.1469-8137.2005.01449.x

Sabate S, Sala A, Gracia CA (1995) Nutrient content in Quercus ilex canopies: seasonal and spatial variation within a catchment. Plant Soil 168:297-304.

https://doi.org/10.1007/BF00029341

See CR, Yanai RD, Fisk MC (2015) Soil nitrogen affects phosphorus recycling: foliar resorption and plant-soil feedbacks in a northern hardwood forest. Ecology 96:2488-2498. https://doi.org/10.1890/15-0188.1

Tully KL, Wood TE, Schwantes AM, Lawrence D (2013) Soil nutrient availability and reproductive effort drive patterns in nutrient resorption in Pentaclethra macroloba . Ecology 94(4):930-940. https://doi.org/10.1890/12-0781.1

Van Heerwaarden LM, Toet S, Aerts R (2003a) Current measures of nutrient resorption efficiency lead to a substantial underestimation of real resorption efficiency: facts and solutions. Oikos 101(3):664-9.

https://doi.org/10.1034/j.1600-0706.2003.12351.x

Van Heerwaarden LM, Toet S, Aerts R (2003b) Nitrogen and phosphorus resorption efficiency and proficiency in six sub-arctic bog species after 4 years of nitrogen fertilization. J Ecol 91:1060-1070. https://doi.org/10.1046/j.1365-2745.2003.00828.x

Vergutz L, Manzoni S, Porporato A et al (2012) Global resorption efficiencies and concentrations of carbon and nutrients in leaves of terrestrial plants. Ecol Monograph 82:205-220. https://doi.org/10.1890/11-0416.1

Wang M, Murphy MT, Moore TR (2014) Nutrient resorption of two evergreen shrubs in response to long-term fertilization in a bog. Oecologia 174:365-377.

https://doi.org/10.1007/s00442-013-2784-7

Wei L, Bee MY, Zhou T (2017) Global patterns in nutrient resorption of mangrove plants. SRCC 7(2):110.

Yuan, Z Y.; Chen, HYH (2015) Negative effects of fertilization on plant nutrient resorption. Ecology96 :373-380. https://doi.org/10.1890/14-0140.1

\section{Supplementary materials}

Table S1: The sediment nutrient distribution.

\begin{tabular}{lllll}
\hline \multicolumn{1}{c}{ Winter } & \multicolumn{3}{c}{ Summer } \\
\hline & Nitrogen $\left(\mathrm{g} \mathrm{kg}^{-1}\right)$ & Phosphorus $\left(\mathrm{g} \mathrm{kg}^{-1}\right)$ & Nitrogen $\left(\mathrm{g} \mathrm{kg}^{-1}\right)$ & Phosphorus $\left(\mathrm{g} \mathrm{kg}^{-1}\right)$ \\
Plot 1 & $1.50 \pm 0.03$ & $0.99 \pm 0.01$ & - & - \\
Plot 2 & $2.50 \pm 0.10$ & $1.86 \pm 0.18$ & $2.12 \pm 0.14$ & $1.25 \pm 0.05$ \\
Plot 3 & $2.05 \pm 0.04$ & $2.22 \pm 0.28$ & $1.65 \pm 0.03$ & $1.33 \pm 0.07$ \\
Plot 4 & $1.60 \pm 0.04$ & $1.26 \pm 0.08$ & $1.43 \pm 0.01$ & $0.89 \pm 0.07$ \\
Plot 5 & $1.93 \pm 0.10$ & $0.84 \pm 0.03$ & $1.52 \pm 0.01$ & $1.22 \pm 0.01$ \\
Plot 6 & $1.49 \pm 0.04$ & $0.73 \pm 0.03$ & $1.77 \pm 0.03$ & $0.87 \pm 0.22$ \\
\hline
\end{tabular}

Figure S1: Location of study site and plots in the stand. The six plots are located between creek-I and creek-II which receiving the effluent from aquaculture ponds. The six plots are on the similar elevations. 


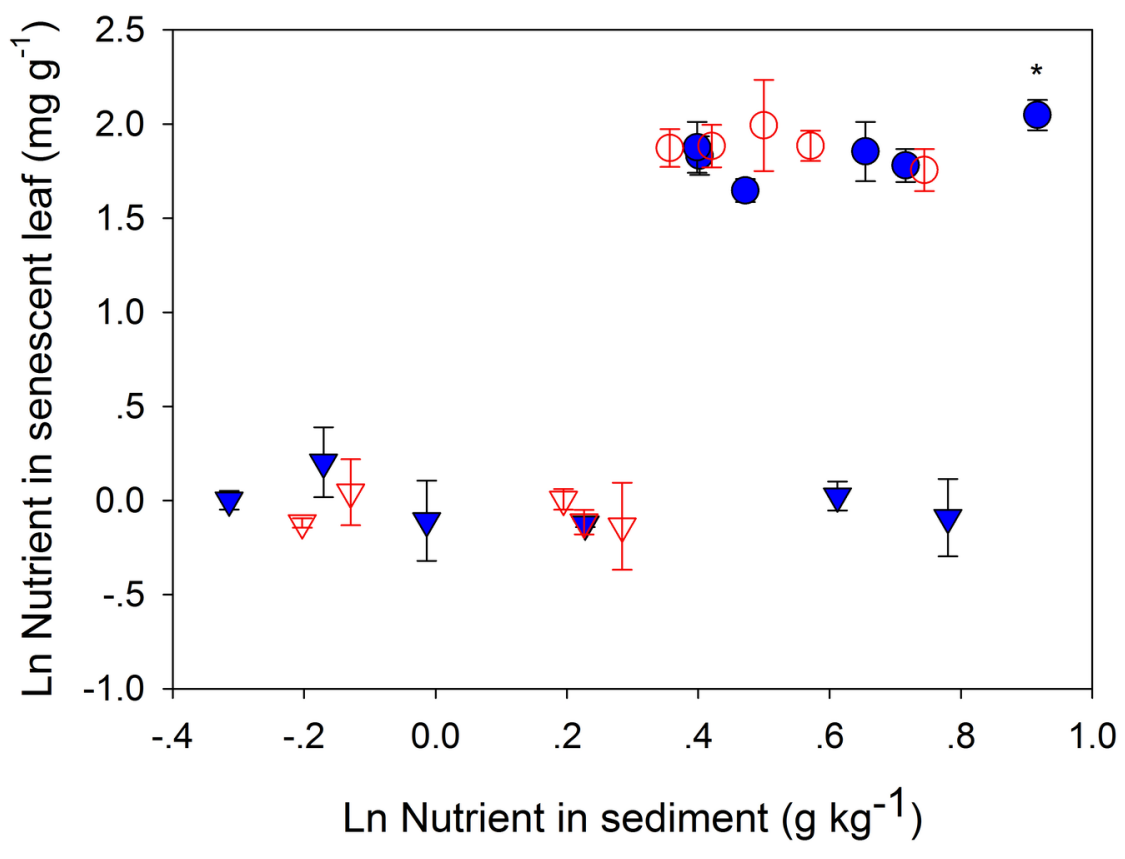



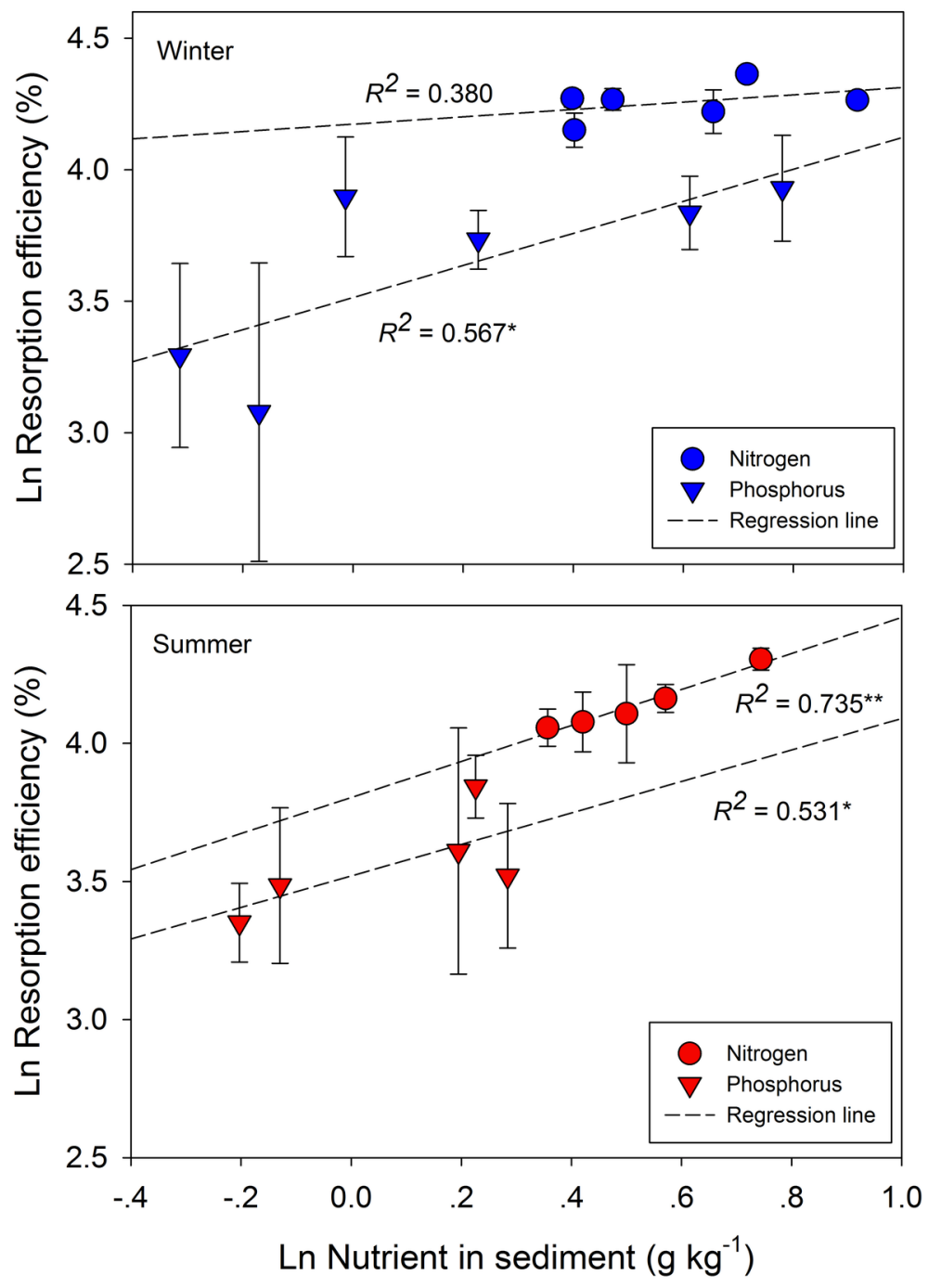


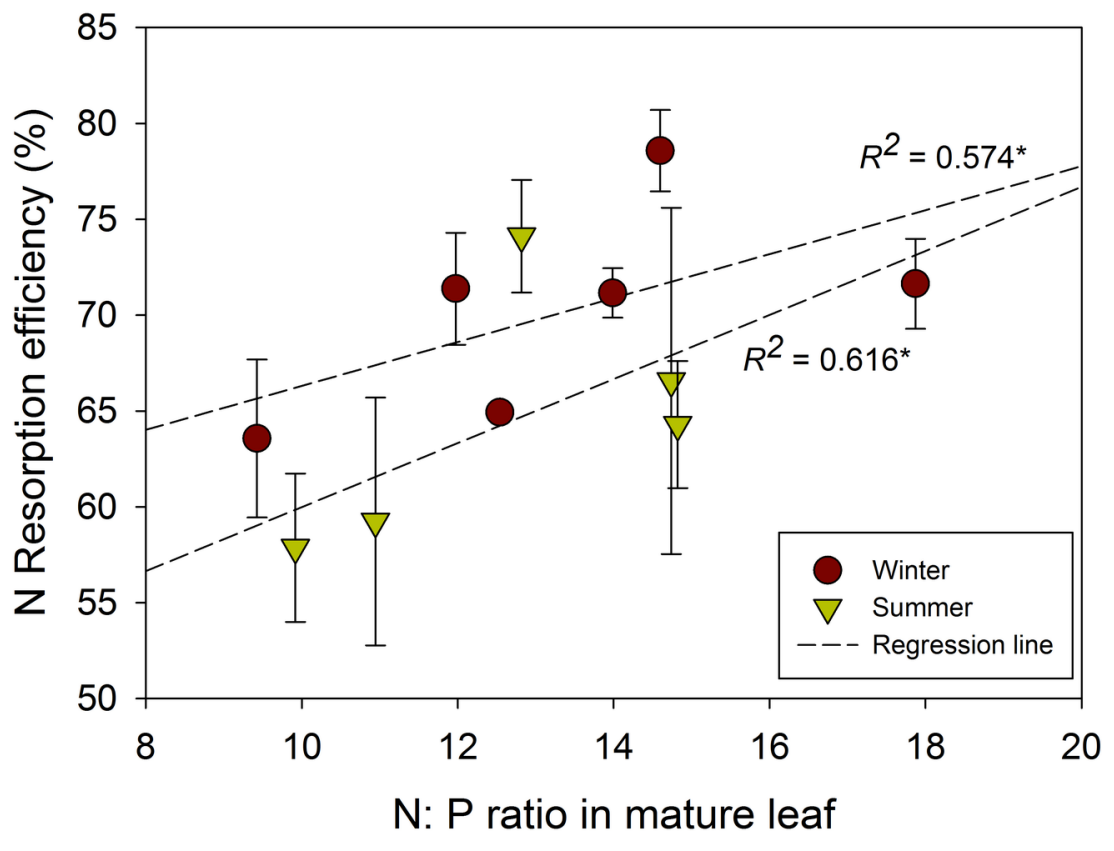

